\title{
DAMPAK STRESS KERJA TERHADAP DISIPLIN ANGGOTA POLRI SEKTOR BELAKANG PADANG ( BLP ) WILAYAH PERBATASAN PERAIRAN INDONESIA - SINGAPURA POLRESTA BARELANG KEPULAUAN RIAU
}

\author{
Mulia Sosiady, SE, M.Si, Ak \\ Ermansyah, SE, MM \\ Dosen Fakultas Ekonomi dan Ilmu Sosial \\ Universitas Islam Negeri Sultan Syarif Kasim Riau
}

\begin{abstract}
Abstrak
Penelitan ini dilaksanakan di Polsek Belakang Padang (BLP) Jalan Hangtuah No 4 Batam, Tujuan penelitian ini adalah untuk mengetahui seberapa besar dampak stress terhadap disiplin kerja pada anggota polisi sektor Belakang Padang (BLP). Latar Belakang masalah menunjukan bahwa wilayah Belakang Padang merupakan kepualauan dan harus menempuh perjalanan laut serta wilayah nya rata-rata adalah pulau-pulau kecil perbatasan Indonesia dan Singapura sehingga kinerja Polisi disana bisa terhambat dan terganngu untuk melayani masyarakat. Hipotesanya dari penelitain ini adalah Diduga ada hubungan antara stres dengan disiplin kerja Aparat Polisi Sektor Belakang Padang (BLP) Batam Kepualauan Riau. Dari hasil pengujian hipotesis dengan menggunakan uji regresi didapatkan bahwa hipotesis 1 menunjukkan bahwa stress kerja berpengaruh signifikan terhadap disiplin kerja, Hasil pengujian secara serentak (uji F), sehingga dapat disimpulkan bahwa secara bersama-sama stress kerja tidak mempunyai pengaruh signifikan terhadap disiplin kerja.

Dari hasil observasi di lapangan bahwa Anggota Polri Sektor Belakang Padang (BLP) tetap disiplin bekerja meskipun tekanan lingkungan kerja yang bisa membuat stres kerja menjadi tinggi. Kinerja Anggota Polri Sektor Belakang Padang ( BLP) sudah lebih baik ditandai mampu melayani masyarakat dengan baik seperti kita berkunjung ke Perbankan. Tingkat stress tinggi dan disiplin kerja yang akan berimbas kepada kinerja Anggota Polri Sektor Belakang Padang ( $B L P$ ) dapat diatasi dengan kemampuan majerial Kapolsek yang baik terutama dimasa kepemimpinan AKP Dasrul Savit yang mampu memimpin dan membina anggota nya dengan baik, AKP Dasrul salah satu Kapolsek Terbaik selama Polsek Belakang Padang berdiri.
\end{abstract}

Kata Kunci : Stress Kerja, Disiplin Kerja, Kinerja Polri, Polsek Belakang Padang (BLP)

\section{PENDAHULUAN}

Dalam setiap organisasi tidak terlepas dari sumber daya manusia. Sumber daya manusia tersebut dituntut memiliki kemampuan yang berkualitas untuk mendukung tercapainya tujuan dalam organisasi. Maju atau mundurnya kehidupan manusia, terwujud atau tidaknya cita-cita manusia tergantung pada sumberdaya manusia, kemampuannya untuk mengatur dan memanfaatkan sumberdaya manusia yang ada dalam organisasi, termasuk sumberdaya manusianya dengan lebih efisien, efektif dan produktif.

Penyempurnaan di bidang personalia selalu mendapat perhatian untuk menuju karyawan yang profesional dengan berbagai pendekatan dan kebijaksanaan. Untuk itu diperlukan adanya pembinaan, penyadaran dan kemauan kerja yang tinggi untuk 
mencapai kinerja yang diharapkan. Apabila karyawan penuh kesadaran dan bekerja secara optimal maka tujuan organisasi akan lebih mudah tercapai. Salah satu sasaran penting dalam manajemen sumberdaya manusia pada suatu organisasi adalah terciptanya kepuasan kerja anggota organisasi yang bersangkutan. Kepuasan kerja tersebut diharapkan pencapaian tujuan organisasi akan lebih baik dan akurat.

Perkembangan ilmu pengetahuan dan teknologi yang sangat pesat, membawa perubahan pula dalam kehidupan manusia. Perubahan-perubahan itu membawa akibat yaitu tuntutan yang lebih tinggi terhadap setiap individu untuk lebih meningkatkan kinerja mereka sendiri dan masyarakat luas. Agar eksistensi tetap terjaga, maka setiap individu akan mengalami stres terutama bagi individu yang kurang dapat menyesuaikan diri dengan perkembangan tersebut.

Kondisi seperti diatas sering memicu terjadinya konflik-konflik yang terjadi dalam kehidupan perusahaan, bila tidak ditangani secara serius akan menimbulkan dampak yang sangat berarti bagi usaha pencapaian tujuan perusahaan, salah satunya adalah rendahnya kinerja karyawan secara keseluruhan akan mempengaruhi produktifitas perusahaan. Akan tetapi tidak hanya itu saja yang ditimbulkan oleh konflik yang tidak ditangani secara tepat dan bijaksana, dapat pula berakibat langsung pada diri karyawan, karena mereka dalam keadaan suasana serba salah sehingga mengalami tekanan jiwa (stres).

Akibat atau dampak dari stres itu sendiri yaitu dampak subjektif (kecemasan, agresi, kebosanan, depresi, keletihan, frustrasi, kehilangan kesabaran, rendah diri, gugup dan merasa kesepian), dampak perilaku (kecendrungan mendapatkan kecelakaan, alkohol, menyalah gunakan obatobatan, emosi yang tiba-tiba meledak, makan berlebihan, merokok berlebihan, perilaku yang mengikuti kata hati, ketawa dan gugup), dampak kognitif (ketidakmampuan mengambil keputusan yang jelas, kosentrasi yang buruk, rentang perhatian yang pendek, sangat peka terhadap kritik, dan rintangan mental, dampak psikologis (meningkatkan kadar gula, meningkatkan denyut jantung dan tekanan darah, kekeringan di mulut, berkeringat, membesarnya pupil mata dan tubuh panas dingin; dampak organisasi (keabsenan, pergantian karyawan, rendahnya produktivitas, ketersaingan dari rekan kerja, ketidakpuasan kerja, menurunnya keterikatan dan kesetiaan terhadap organisasi).

Peningkatan sikap, perjuangan, pengabdian, disiplin kerja, dan kemampuan profesional dapat dilakukan melalui serangkaian pembinaan dan tindakan nyata agar upaya peningkatan prestasi kerja dan loyalitas karyawan dapat menjadi kenyataan. Salah satu faktor yang mempengaruhi loyalitas karyawan adalah kepuasan kerja karyawan. Kepuasan kerja yang dimaksud disini adalah suatu perasaan yang menyokong atau tidak menyokong diri pegawai yang berhubungan dengan pekerjaannya maupun dengan kondisi dirinya. Perasaan yang berhubungan dengan pekerjaan yang melibatkan aspek-aspek seperti upah atau gaji yang diterima, kesempatan pengembangan karir, hubungan dengan pegawai lainnya, penempatan kerja, jenis pekerjaan, struktur organisasi perusahaan, mutu pengawasan. Sedangkan perasaan yang berhubungan dengan dirinya, antara lain umur, kondisi kesehatan, kemampuan, pendidikan.

Polsek Belakang Padang (BLP) adalah Polsek diwilayah Hukum Polresta Barelang Batam, Wilayah Belakang Padang yang notabene adalah kepualauan dan harus menempuh perjalanan laut serta wilayah nya rata-rata adalah pulau-pulau kecil perbatasan indonesia dan Singapura sehingga Kinerja Polisi disana bisa terhambat dan terganngu untuk melayani masyarakat, dan biasanya rata-rata polisi wilayah kepualauan tidak tinggal langsung di pulau tersebut dan jika 
kondisi nya demikian bisa sangat menghambat kinerja mereka apalagi ini wilayah yang sangat jauh bisa membuat polisi diwilayah tersebut tingkat stress nya bisa jadi tinggi karena sangat jauh dengan kondisi perkotaan dan letak wilayah bisa menggangu kedispilan mereka dalam bertugas. Wilayah yang sangat jauh dan luas Polsek Belakang Padang (BLP) hanya memiliki 14 Anggota ditambah dengan 18 Polisi Wilyah Perbatasan Perairan Indonesia Singapura, sehingga tingkat Stress Kerja dan Disiplin Kerja bisa menjadi suatu hubungan yang erat, dan dapat mempengaruhi Kinerja anggota Polri tersebut.

Tabel I : Jumlah Personel Polisi Sektor Belakang Padang (BLP)

\begin{tabular}{|l|l|c|}
\hline No & \multicolumn{1}{|c|}{ Wilayah } & $\begin{array}{c}\text { Jumlah } \\
\text { Personel }\end{array}$ \\
\hline 1 & Pulau Belakang Padang & 14 \\
\hline 2 & Pulau Tanjung Sari & 2 \\
\hline 3 & Pulau Sekanak Raya & 2 \\
\hline 4 & Pulau Pemping & 2 \\
\hline 5 & Pulau Pecong & 4 \\
\hline 6 & Pulau Kasu & 4 \\
\hline 7 & Pulau Terong & 4 \\
\hline \multicolumn{2}{|c|}{ Jumlah } & $\mathbf{3 2}$ \\
\hline
\end{tabular}

Sumber : Polsek Belakang Padang (BLP) Wilayah Perbatasan Perairan Indonesia Singapura Polresta Barelang Kepri 2013

Dari data diatas bisa dilihat bahwa personel Polisi Sektor Belakang Padang Wilayah Perbatasan Singapura - Indonesia Hanya berjumlah 32 Orang yang terdiri dari 14 Polisi di Pulau Belakang Padang dan 18 orang personel di Pulau terluar yang terdiri dari 6 pulau kecil yang langsung berbatasan dengan Negara Singapura. Keterbasan jumlah personel dan jarak antara pulau yang sangat jauh dan peralatan pendukung yang sangat terbatas bisa memunculkan stress kerja yang sangat tinggi yang bisa mempengaruhi Disiplin dan Kinerja anggota Polisi Sektor Belakang Padang Wilayah Perbatasan Indonesia Singapura tersebut.

\section{KERANGKA TEORITIK 1. Pengertian Stress Kerja}

Definisi stres kerja menurut Weather (2002:623) "Work stres is an individual's response to work related environmental stresors. Stres as the reaction of organism, which can be physiological, psychological, or behavioural reaction".

Berdasarkan definisi di atas, stres kerja dapat diartikan sebagai sumber atau stresor kerja yang menyebabkan reaksi individu berupa reaksi fisiologis, psikologis, dan perilaku. Seperti yang telah diungkapkan di atas, lingkungan pekerjaan berpotensi sebagai stresor kerja. Stresor kerja merupakan segala kondisi pekerjaan yang dipersepsikan karyawan sebagai suatu tuntutan dan dapat menimbulkan stres kerja. Menurut Siagian (2006:300) stres merupakan kondisi ketegangan yang berpengaruh terhadap emosi, jalan pikiran dan kondisi fisik seseorang. Selanjutnya Davis (2003:193) menyatakan stres adalah suatu kondisi ketegangan yang mempengaruhi emosi, jalan pikiran, dan kondisi fisik seseorang.Handoko menyebutkan stres dapat sangat membantu atau fungsional, tetapi juga dapat berperan salah (dysfunctional) atau merusak prestasi kerja. Secara sederhana hal ini berarti bahwa stress mempunyai stres mempunyai potensi untuk mendorong atau mengganggu pelaksanaan kerja, tergantung seberapa besar tingkat stres. Bila tidak ada stres, tantangan-tantangan juga tidak ada, dan prestasi kerja juga cendrung rendah. Sejalan dengan meningkatnya stres, prestasi kerja cendrung naik, karena stres juga membantu karyawan untuk mengerahkan segala sumber daya dalam memenuhi berbagai persyaratan atau kebutuhan pekerjaan (Handoko, 2002:202).

Menurut Siagian (2006:300) sumber stres digolongkan menjadi 2 bagian, yaitu:

1. Stres yang berasal dari dalam pekerjaan: beban tugas yang terlalu berat, desakan 
waktu, penyeliaan yang kurang baaik, iklim kerja yang menikmbulkan rasa tidak aman, kurangnya informasi atau umpan balik tentang prestasi kerja seseorang, krtidakseimbangan antara wewenang dengan tanggung jawab, ketidakjelasan peranan seseorang dalam organisasi, Intervensi pihak lain, konflik antar karyawan, Perbedaan sistem nilai yang dianut antara karyawan dengan organisasi

2. Stres yang berasal dari luar pekerjaan: masalah keuangan, perilaku negative anak-anak, kehidupan keluarga yang tidak atau kurang harmonis, pindah tempat tinggal, ada anggota keluarga yang meninggal, kecelakaan,

Stres dapat timbul sebagai akibat tekanan atau ketegangan yang bersumber dari ketidakselarasan antara seseorang dengan lingkungannnya. Apabila sarana dan tuntutan tugas tidak selaras dengan kebutuhan dan kemampuan seseorang, maka ia akan mengalami stres. Namun secara umum faktor pribadi merupakan sumber utama munculnya stres. Secara umum dikelompokkan sebagai berikut: (Rivai 2012:1)

1. Tidak adanya dukungan sosial. Artinya, stres akan cendrung muncul pada para karyawan yang tidak mendapat dukungan dari lingkungan sosial mereka. Dukungan sosial disini bisa berupa dukungan dari lingkungan pekerjaan maupun lingkungan keluarga.

2. Tidak adanya kesempatan berpartisipasi dalam pembuatan keputusan di kantor. Hal ini berkaitan dengan hak dan kewenangan seseorang dalam menjalan tugas dan pekerjaannya.

3. Pelecehan seksual. Yakni, kontak atau komunikasi yang berhubungan atau dikonotasikan berkaitan dengan seks yang tidak diinginkan.

Stres akan berpengaruh terhadap prestasi kerja sebagaimana yang dikemukakan oleh Gibson (2004:207) adalah konsekwensi atau dampak dari stres yaitu dampak subjektif (kecemasan, agresi, kebosanan, depresi, keletihan, frustrasi, kehilangan kesabaran, rendah diri, gugup dan merasa kesepian), dampak perilaku (kecendrungan mendapatkan kecelakaan, alkohol, menyalahgunakan obat-obatan, emosi yang tiba-tiba meledak, makan berlebihan, merokok berlebihan, perilaku yang mengikuti kata hati, ketawa dan gugup), dampak kognitif (ketidakmampuan mengambil keputusan yang jelas, kosentrasi yang buruk, rentang perhatian yang pendek, sangat peka terhadap kritik, dan rintangan mental), dampak psikologis (meningkatkan kadar gula, meningkatkan denyut jantung dan tekanan darah, kekeringan di mulut, berkeringat, membesarnya pupil mata dan tubuh panas dingin); dampak organisasi (keabsenan, pergantian karyawan, rendahnya produktivitas, ketersaingan dari rekan kerja, ketidakpuasan kerja,menurunnya keterikatan dan kesetiaan terhadap organisasi).

Menurut Braham dalam Agung (2012:1), gejala stres dapat berupa tandatanda berikut ini :

1. Fisik, yaitu sulit tidur atau tidur tidak teratur, sakit kepala,sulit buang air besar, adanya gangguan pencernaan, radang usus, kulit gatal-gatal, punggung terasa sakit, urat-urat pada bahu dan leher terasa tegang, keringat berlebihan, berubah selera makan,tekanan darah tinggi atau serangan jantung, kehilangan energi.

2. Emosional,yaitu marah-marah, mudah tersinggung dan terlalu sensitif, gelisah dan cemas, suasana hati sering berubahubah, sedih, mudah menangis dan depresi, gugup, agresif terhadap orang lain dan mudah bermusuhan serta mudah menyerang dan kelesuan mental.

3. Intelektual, yaitu mudah lupa, kacau pikirannya, daya ingat menurun, sulit untuk berkonsentrasi, suka melamun berlebihan, pikiran hanya dipenuhi satu pikiran saja. 
4. Interpersonal, yaitu acuh dan mendiamkan orang lain, kepercayaan pada orang lain menurun, mudah mengingkari janji pada orang lain, senang mencari kesalahan orang lain atau menyerang dengan kata-kata, menutup diri secara berlebihan, an mudah menyalahkan orang lain.

Cara mengatasi stress kerja, terdapat tiga pola untuk mengatasi stress kerja yaitu pola harmonis, pola sehat, dan pola psikologi. Penjelasannya sebagai berikut:

1. Pola sehat adalah pola mengahadapi stress dengan kemampuan mengelola perilaku dan tindakan sehingga adanya stress yang tidak menimbulkan gangguan, akan menjadi lebih sehat dan berkembang. Mereka yang tergolong kelompok ini biasanya mampu mengelola waktu dan kesibukan dengan cara yang baik dan teratur sehingga ia tidak perlu merasa ada sesuatu yang menekan, meskipun sebenarnya tantangan dan tekanan cukup banyak

2. Pola harmonis adalah pola menghadapi stress dengan kemampuan mengellola waktu dan kegiatan secara harmonis dan tidak menimbulkan berbagai hambatan. Dalam pola ini, individu mampu mengendalikan berbagai kesibukan dan tantangan dengan cara mengatur waktu secatra teratur. Iapun selalu menghadapi tugas secara tepat, dan kalau perlu ia mendelegasikan tugas-tugas tertentu kepada orang lain dengan memberikan kepercayaan penuh. Dengan demikian, akan terjadi keharmonisan dan keseimbangan antara tekanan yang diterima dengan reaksi yang diberikan. Demikian juga juga terhadap keharmonisan antara dirinya dan lingkungan.

Pola patologis adalah pola menghadapi stress dengan berdampak berbagai gangguan fisik maupun sosiologipsikologis. Dalam pola ini, individu akan mengahadapi berbagai macam tantangan dengan cara-cara yang tidak memiliki kemampuan dan keteraturan mengelola tugas dan waktu. Cara ini dapat menimbulkan reaksi-reaksi yang berbahaya karena bias menimbulkan berbagai masalah-masalah yang buruk.

\section{Pengertian Disiplin Kerja}

Disiplin kerja merupakan cerminan sejauh mana besarnya rasa tanggung jawab dan pengabdian seseorang terhadap tugas dan tanggung jawabnya. Secara etimologis disiplin berasal dari bahasa inggris "discipline" yang berarti pengikut atau penganut pengajaran, latihan dan sebagainya. Sinungan (2005:145) menyatakan disiplin merupakan suatu keadaan tertentu dimana orang-orang yang tergabung dalam organisasi tunduk pada peraturan-peraturan yang ada dengan rasa senang hati. Sedangkan kerja adalah segala aktivitas manusia yang dilakukan untuk menggapai tujuan yang telah ditetapkannya. Prijodarminto (2004:15) mengemukakan "Disiplin adalah suatu kondisi yang tercipta dan terbentuk melalui proses dari serangkaian perilaku yang menunjukkan nilai-nilai ketaatan, kepatuhan, keteraturan dan ketertiban". Karena sudah menyatu dengan dirinya, maka sikap atau perbuatan yang dilakukan bukan lagi atau sama sekali tidak dirasakan sebagai beban, bahkan sebaliknya akan membebani dirinya bilamana ia tidak berbuat sebagaimana lazimnya. Nilai-nilai kepatuhan telah menjadi bagian dari perilaku dalam kehidupannya yang berkembang sesuai dengan nilai-nilai sosial yang baik dari keluarga maupun dari lingkungan sekitarnya. Dalam bukunya yang lain ia berpendapat "Disiplin terbagi pada tiga aspek yaitu sikap mental, pemahaman dan sikap kelakuan": diuraikan sebagai berikut:

1. Sikap mental (mental attitude), yang merupakan sikap taat dan tertib sebagai hasil atau pengembangan dari latihan, 
pengendalian pikiran dan pengendalian watak;

2. Pemahaman yang baik mengenai sistim aturan perilaku, norma, kriteria, dan standar yang sedemikian rupa, sehingga pemahaman tersebut menumbuhkan pengertian yang mendalam atau kesadaran, bahwa ketatan akan aturan, norma, kriteria, dan standar tadi merupakan syarat mutlak untuk mencapai keberhasilan (sukses);

3. Sikap kelakuan yang secara wajar menunjukkan kesanggupan hati, untuk mentaati segala hal secara cermat dan tertib.

Disiplin kerja yang diterapkan merupakan alat komunikasi pimpinan seperti dikemukakan oleh Rivai (2004:44) yang menyebutkan bahwa "Disiplin kerja adalah suatu alat yang digunakan para manajer untuk mengubah suatu perilaku serta sebagai suatu upaya untuk meningkatkan kesadaran dan kesediaan seseorang mentaati semua peraturan perusahaan dan norma-norma sosial yang berlaku“". Dari pengertian disiplin kerja yang telah dikemukakan di atas, terkandung pengertian tanggung jawab dan ketaatan. Kedua kata tersebut menunjukkan suatu sikap mental yang harus dimiliki oleh seorang pegawai dalam melaksanakan tugasnya. Untuk itu penulis akan menjelaskan pengertian istilah tanggung jawab dan ketaatan. Untuk mencapai hasil yang baik sesuai dengan tujuan yang telah ditetapkan, perlu adanya disiplin kerja yang baik dari personil yang bersangkutan. Hasibuan (2006:212) mengemukakan bahwa, "Disiplin yang baik mencerminkan besarnya rasa tanggung jawab seseorang terhadap tugastugas yang diberikan kepadanya". Karena hal ini akan mendorong gairah kerja atau semangat kerja, dan mendorong terwujudnya tujuan organisasi.

Kedisiplinan harus ditegakkan dalam suatu organisasi karena tanpa dukungan disiplin personil yang baik, maka organisasi akan sulit dalam mewujudkan tujuannnya. Jadi dapatlah dikatakan bahwa kedisiplinan merupakan kunci keberhasilan suatu organisasi dalam mencapai tujuan yang telah ditentukan. Dari sekian banyak kewajiban yang harus dipenuhi, dalam setiap pelaksanaannya tidak selalu berjalan seperti apa yang diharapkan. Hal ini dikarenakan dalam pelaksanaan disiplin selalu dibarengi dengan adanya pelanggaran terhadap peraturan dan ketentuan yang berlaku. Pelanggaran terhadap disiplin ini dapat berupa perbuatan-perbuatan yang tidak sesuai dengan ketentuan-ketentuan dan norma yang telah ada.

Handoko (2002:208) menyatakan bahwa disiplin kerja dibagi menjadi disiplin preventif, disiplin korektif dan disiplin progresif. Disiplin preventif adalah disiplin yang ditujukan untuk mendorong pegawai agar berdisiplin diri dengan mentaati dan mengikuti berbagai standar dan peraturan yang telah ditetapkan. Seperti yang dikemukakan oleh Mangkunegara (2007:129) bahwa: "Disiplin preventif adalah suatu upaya untuk menggerakkan pegawai mengikuti dan mematuhi pedoman kerja, aturan-aturan yang telah digariskan oleh perusahaan." Handoko (2002:208) mengemukakan bahwa: "Disiplin preventif adalah kegiatan yang dilakukan untuk mendorong para karyawan agar mengikuti berbagai standar dan aturan, sehingga penyelewengan-penyelewengan dapat dicegah." Dengan demikian disiplin preventif merupakan suatu upaya yang dilakukan oleh organisasi untuk menciptakan suatu sikap dan iklim organisasi di mana semua anggota organisasi dapat menjalankan dan mematuhi peraturan yang telah ditetapkan atas kemauan sendiri. Adapun fungsi dari disiplin preventif adalah untuk mendorong disiplin diri para pegawai sehingga mereka dapat menjaga sikap disiplin mereka bukan karena paksaan. 
Disiplin korektif merupakan disiplin
yang dimaksudkan untuk menangani pelanggaran terhadap aturan-aturan yang berlaku dan memperbaikinya untuk di masa yang akan datang. Hal ini sejalan dengan yang dikemukakan oleh Mangkunegara (2007:129) bahwa: "Disiplin korektif adalah suatu upaya untuk menggerakan pegawai dalam menyatukan suatu peraturan dan mengarahkan untuk tetap mematuhi peraturan sesuai dengan pedoman yang berlaku dalam perusahaan." Di samping itu Handoko (2002:208) mengemukakan bahwa: "Disiplin Korektif adalah kegiatan yang diambil untuk menangani pelanggaran terhadap peraturanperaturan dan mencoba untuk menghindari pelanggaran lebih lanjut." Berdasarkan pernyataan di atas maka dapat disimpulkan bahwa disiplin korektif merupakan suatu upaya untuk memperbaiki dan menindak pegawai yang melakukan pelanggaran terhadap aturan yang berlaku. Dengan kata lain sasaran dari disiplin korektif adalah para pegawai yang melanggar aturan dan diberi sanksi yang sesuai dengan aturan yang berlaku. Disiplin korektif ini dilakukan untuk memperbaiki pelanggaran dan mencegah pegawai yang lain melakukan perbuatan yang serupa dan mencegah tidak adanya lagi pelanggaran dikemudian hari.

Disiplin progresif merupakan pemberian hukuman yang lebih berat terhadap pelanggaran yang berulang. Tujuannya adalah memberikan kesempatan kepada pegawai untuk mengambil tindakan korektif sebelum hukuman-hukuman yang lebih serius. Dilaksanakan disiplin progesif ini akan memungkinkan manajemen untuk membantu pegawai memperbaiki kesalahan. Seperti yang dikemukakan oleh Rivai (2004:447) bahwa: "Disiplin progresif dirancang untuk memotivasi karyawan agar mengoreksi kekeliruannya secara sukarela". Contoh dari disiplin progresif adalah : teguran secara lisan oleh atasan ; skorsing pekerjaan; diturunkan pangkat atau; dipecat.

\section{METODE PENELITIAN}

1. Lokasi dan Waktu Penelitian

Adapun lokasi penelitian ini adalah di Sektor Belakang Padang ( BLP ) Wilayah Perbatasan Perairan Indonesia - Singapura Polresta Barelang Jln. Hangtuah No 4 Batam Kepulauan Riau.

2. Jenis dan Sumber Data

Data Primer yaitu data penelitian yang diperoleh dari hasil penelitian langsung ke lapangan, seperti jawaban responden yang menggambarkan terhadap stress dan disiplin kerja aparat kepolisian di sektor Belakang Padang (BLP) Wilayah Perbatan Perairan Indonesia - Singapura Polresta Balerang Kepulauan Riau. Untuk maksud tersebut peneliti menggunakan angket.

Data Sekunder yaitu segala informasi yang diperlukan untuk menyusun data-data penelitian baik berupa, konsep, atau teoriteori yang dapat dipergunakan untuk menjelaskan permasalahan. Untuk maksud tersebut penulis menggunakan metode kepustakaan.

3. Teknik Pengumpulan Data

Angket adalah lembaran pertanyaan yang dibagikan kepada anggota Polri Polsek Belakang Padang (BLP) Wilayah Perbatasan Perairan Indonesia - Singapura Polresta Barelang Kepulauan Riau. Angket ini bertujuan untuk memperoleh data mengenai stress dan disiplin kerja anggota polisis. Untuk itu diharapkan kepada seluruh responden dapat menjawab seluruh pertanyaan yang diajukan dalam angket, dan semua pertanyaan dalam angket atau kuesioner tersebut disajikan dalam bentuk skala Guttman.

Teknik wawancara ini dipergunakan untuk memperoleh data dari anggota polisi sektor Belakang Padang (BLP) Wilayah Perbatasan Perairan Indonesia - Singapura Polresta Barelang Kepulauan Riau berkaitan dengan stress maupun memperoleh informasi dari anggota polisi sektor Belakang Padang (BLP) berkaitan dengan disiplin kerja. 


\section{Teknik Analisis Data}

Teknik analisis korelasi yang dipergunakan adalah Korelasi Product Moment yang dikemukakan oleh Pearson. Teknik ini termasuk teknik statistik parametrik yang menggunakan data interval dan ratio dengan persyaratan tertentu. Pada langkah terakhir pengolahan data adalah menguji keberartian koofisien korelasi (tingkat signifikansi) dengan menggunakan rumus:

$$
t=\frac{r \sqrt{n-2}}{\sqrt{1-r^{2}}}
$$

Keterangan:

$\mathrm{T}=$ nilai $\mathrm{t}$ yang dicari

$\mathrm{r}^{2}=$ koofisien korelasi

$\mathrm{n}=$ banyaknya data

Selanjutnya $t_{\text {hitung }}$ dibandingkan dengan nilai $t_{\text {tabel }}$ dengan $d k \mathrm{n}-2$ pada taraf atau tingkat kepercayaan yang dipilih, dalam hal ini adalah $95 \%$. Apabila $t_{\text {hitung }}<t_{\text {tabel }}$, maka dapat disimpulkan hipotesis diterima atau dengan kata lain hipotesis nol ditolak.

\section{HASIL DAN PEMBAHASAN 1. Uji Validitas}

Kuesioner dapat dikatakan valid jika nilai Pearson Korelation lebih besar dari nilai $r$ tabel, $r$ tabel dicari pada signifikansi 0,05 dengan uji 2 sisi dan jumlah data $(n)=32$, maka $r$ tabelnya adalah 0,349 . Untuk variabel independen dan dependen, dari hasil uji validitas dapat disajikan sebagai berikut:

Setelah dilakukan uji validitas, nilai korelasi semua butir pernyataan masingmasing variabel stress kerja dan variabel disiplin kerja. Dilihat dari kriteria $r$ tabel 0,349 dan semua butir pernyataan lebih besar dari angka $r$ tabel 0,349.Dengan demikian maka dapat disimpulkan bahwa semua item masing-masing pernyataan memenuhi syarat untuk valid dan layak untuk digunakan sebagai data penelitian.

\section{Uji Reliabilitas}

Pengujian reabilitas digunakan untuk mengetahui sejauh mana pengukuran dapat memberikan hasil yang relatif sama atau tidak berbeda (relative konsisten), bila dilakukan pengulangan pengukuran terhadap obyek yang sama. Dalam penelitian ini pengukuran menggunakan teknik Croanbach alpha.Alat ukur dapat dikatakan andal apabila memiliki alpha lebih dari 0,60

\begin{tabular}{|c|l|c|c|c|}
\hline No & Variabel & $\begin{array}{c}\text { Jumlah } \\
\text { Item } \\
\text { dalam } \\
\text { Kuesioner }\end{array}$ & $\begin{array}{c}\text { Cronbach's } \\
\text { Alpha }\end{array}$ & Ket \\
\hline 1 & $\begin{array}{l}\text { Disiplin } \\
\text { Kerja } \\
(Y)\end{array}$ & 8 & 0,968 & Reliabel \\
\hline 2 & $\begin{array}{l}\text { Stres } \\
\text { Kerja } \\
(X)\end{array}$ & 12 & 0,927 & Reliabel \\
\hline
\end{tabular}

Sumber : Data Olahan

Pada tabel ini menjelaskan bahwa setelah dilakukan uji reliabilitas, nilai cronbach alpha masing-masing variabel disiplin kerja dan stres kerja adalah 0,968 dan 0,927 yang berarti semua variabel tersebut dinyatakan reliabel dengan keputusan yang sangat baik, karena memiliki nilai koefisien alpha diatas 0,60.

\section{Uji Normalitas Data}

Pengujian normalitas data dilakukan untuk mengetahui apakah rata-rata jawaban responden berdistribusi dengan normal atau tidak. Dalam uji normalitas ini peneliti akan menggunakan uji One Sample KolmogorovSmirnov dengan menggunakan taraf signifikansi 0,05 . Data dinyatakan berdistribusi normal jika signifikansi lebih besar dari $5 \%$ atau 0,05 . 


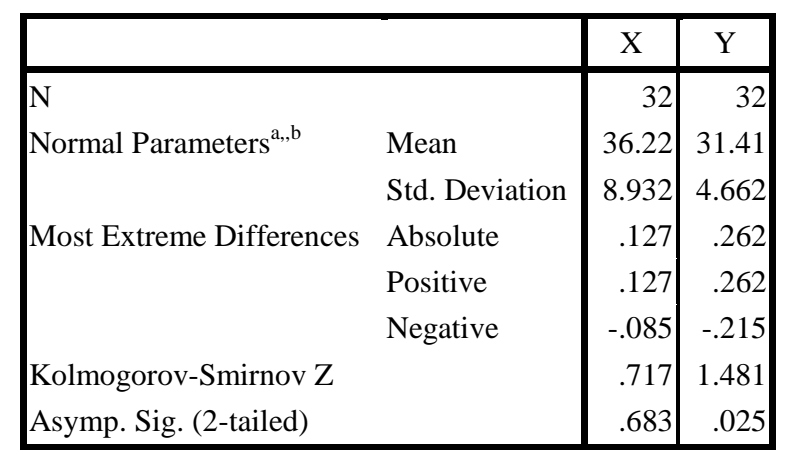

a. Test distribution is Normal.

b. Calculated from data.

Sumber : Data Olahan tahun 2013

Dari tabel diatas, dapat kita lihat pada kolom Kolomogorov-Sminornov dan dapat diketahui bahwa nilai signifikansi untuk stress kerja sebesar 0,717 dan disiplin kerja sebesar 1,481 maka dapat disimpulkan bahwa data pada variabel stress kerja dan disiplin kerja berdistribusi normal.

\section{Hasil Wawancara Peneliti dengan Kapolsek Belakang Padang ( BLP ) AKP Dasrul Savit}

Peneliti : Selama Bapak jadi Kapolsek Belakang Padang ( BLP ), Bagaimana teknik bapak memimpin?

AKP Dasrul Savit : Dalam Kepimpinan Kepolisian dengan sistem Komando tapi melakukannya dengan pendekatan persuasif dan juga harus menjunjung tinggi demokrasi, Budaya organisasi yang terkenal selama ini Polisi identtik dengan Tegas dan Keras, sekarang menjadi Tegas dan Melayani.

Peneliti: Ketika terjadi pemasalahan pada anggota Polsek Belakang Padang ( BLP ) cara apa yang bapak lakukan?

AKP Dasrul Savit : Memanggil bawahan yang melakukan kesalahan, dan tidak diktator dalam menyelesaikan permasalahan, karena gaya diktator akan memunculkan masalah baru, dan tidak lupa kapolsek juga selalu menyampaikan bahwa polisi harus melaksanakan Manajemen Berbasis Kinerja harus dijalankan

Peneliti : Solusi apa yang bapak berikan ketika terjadi permasalahan?
AKP Dasrul Savit : Yang pertama jelas kita berikan teguran sesuai dengan tingkat kesalahannya, kalau terjadi indispliner baru akan dibawa Bagian Provost yang berwenang menangani anggota yang bermasalah, Selain itu juga kita akan memanggil orang tua yang bersangkutan, sehingga tidak terjadi salah komunikasi mengapa kita beri hukuman karena yang bersangkutan sedang bermasalah.

Karena Kepolisian sudah mendapatkan program Remunerasi , jadi salah satu hukuman buat anggota POLRI bermasalah yaitu pengurangan Remunerasi meskipun ada standar pengurangannya.

Peneliti : Cara seperti apa yang bapak gunakan untuk memotivasi bawahan supaya disiplin dan mampu meningkatkan kinerja?

AKP Darul Savit : Sebelum kita memberi perintah disiplin buat anggota, saya sebagai Kapolsek lebih dahulu memberi contoh dispilin kepada mereka, karena yang namanya anggota pasti mencontoh atasannya, sehingga ketika atasan disiplin, anggota pasti ikut disiplin, Komitmen dari atasan Kapolsek maupun Wakapolsek untuk selalu disiplin akan menjadi komitmen bersama seluruh jajaran polsek Belakang Padang ( BLP)

Peneliti : Apakah bapak pernah memberikan Reward atau penghargaan kepada anggota supaya mereka semangat dalam bekerja?

AKP Dasrul Savit : pemberian hadiah secara langsung mungkin tidak pernah saya berikan kepada anggota tapi penghargaan berupa pujian kepada mereka ketika kita melaksanakan apel pagi, saya akan sampaikan bahwa salah satu anggota kita di polsek belakang padang (BLP) sangat disiplin dalam tugas atau memberikan pujian jika berhasil menjalankan tugas lainnya.

Jika terjadi masalah indispliner anggota, juga akan disampaikan saat apel, tetapi untuk menjaga nama baik anggota tersebut hanya disampaikan ketika yang bersangkutan tidak ada di tempat. Kita juga melaksanakan 
berbagai kegiatan acara di polsek bersama masyarakat sekitarnya.

Peneliti : Bagaimana cara bapak memberikan hukuman kepada anggota yang melakukan kesalahan?

AKP Dasrul Savit : Jika pelanggran itu menurut saya hanya pelanggran ringan oleh anggota, saya perintahkan yang bersangkutan mendapatkan hukuman berlari disekitar polsek dan hukuman Pust Up, Hukuman ini mendidika dan juga sekalian berolahraga untuk menjaga stamina anggota. Dan tidak semua kesalahan anggota kita bapak ke ranah hukum selagi bisa di proses di lingkungan polsek kita beri saja pembinaan karena kita punya kasi provost sebagai pembina para anggota.

Peneliti : Selama Bapak menjadi Kapolsek, Program apa yang sudah dilaksanakan dan yang belum bisa dilaksanaka/Terealisasi?

AKP Dasrul Savit : Insyaalah programprogram sudah terlaksana tinggal kedepannya dimaksimalkan saja, program yang selama ini kita buat adalah Perubahan budaya, Saya selalu tekankan bahwa polisi adalah mitra masyarakat bukan lawan masyarakat yang selama ini terjadi masyarakat cendrung takut bermitra dengan polisi. Program pelayanan prima (Quick Win) program ini dari Kapolda Kerpi yang kita terapkan di Polsek masingmasing.

Kita juga memberikan pembinaan kepada masyakarat, sosialisasi bahaya narkoba, bahaya dunia maya dan banyak lagi.

Peneliti : Apa kendala bapak dalam melaksanakan program-program selama menjadi Kapolsek Belakang Padang ( BLP)?

AKP Dasrul Savit : Kita bisa lihat bahwa secara geografis kecamatan Belakang Padang ini adalah wilayah kepulauan antar wilayahnya sangat jauh sekali harus ditempuh dengan waktu yang cukup lama, ini bisa menghambat kegiatan-kegiatan yang kita laksanakan, tapi komitmen kami dengan wilayah seperti ini kita kami tetap dapat bekerja dengan baik. Kemudian biaya yang tinggi kadang menghambat tetapi biasa kita atasi dengan semangat anggota dalam melayani masyarakat.

\section{KESIMPULAN DAN SARAN}

1. Kesimpulan

a. Pengujian hipotesis 1 menunjukkan bahwa stress kerja berpengaruh signifikan terhadap disiplin kerja, yaitu tercermin dari nilai t hitung sebesar 0,705 dengan $\mathrm{t}$ tabel 1,694. Karena 0,705 $<1,694$, maka dapat disimpulkan bahwa hipotesis 1 ditolak, namun signifikan dari stres kerja sebesar 0,486 ini berarti stress kerjatidak berpengaruh signifikan terhadap disiplin kerja. Hasil dari pengujian, variabel stress kerja tidak mempengaruhi disiplin kerja.

b. Hasil pengujian secara serentak (uji F), sehingga dapat disimpulkan bahwa secara bersama-sama stress kerja tidak mempunyai pengaruh signifikan terhadap disiplin kerja.

c. Dari hasil observasi di lapangan bahwa Anggota Polri Sektor Belakang Padang (BLP) tetap disiplin bekerja meskipun tekanan lingkungan kerja yang bisa membuat stres kerja menjadi tinggi.

d. Kinerja Anggota Polri Sektor Belakang Padang ( BLP) sudah lebih baik ditandai mampu melayani masyarakat dengan baik seperti kita berkunjung ke Perbankan.

e. Tingkat stress tinggi dan disiplin kerja yang akan berimbas kepada kinerja Anggota Polri Sektor Belakang Padang ( BLP ) dapat diatasi dengan kemampuan majerial Kapolsek yang baik terutama dimasa kepemimpinan AKP Dasrul Savit yang mampu memimpin dan membina anggota nya dengan baik, AKP Dasrul salah satu Kapolsek Terbaik selama Polsek Belakang Padang berdiri.

\section{Saran}

a. Untuk meningkatkan disiplin kerja diperlukan adanya peningkatan 
kompetensi para Anggota Polri Sektor Belakang Padang (BLP) yakni dengan pemberian pelatihan-pelatihan serta diberikan kesempatan kepada para anggota polri untuk mengikuti kursuskursus atau peningkatan kemampuan dan keterampilan sehingga dalam pelaksanaan tugasnya seorang polri dapat bekerja secara objektif dan bekerja sesuai dengan yang telah ditetapkan.

b. Untuk meningkatkan kinerja Anggota Polri Sektor Belakang Padang (BLP) fasilitas opersasional seharusnya dimodernisasi dan secara kuantitas ditambah karena secara geografis wilayah Belakang Padang termasuk wilayah kepulauan terluar dekat dengan perbatasan ke Negara Singapura.

c. Untuk meningkatkan Disiplin Kerja sebaiknya memberikan reward/penghargaan kepada anggota Polri yang disiplin dalam berdinas.

d. Untuk mengatasi tingkat Stress kerja yang tinggi sebaiknya Polsek mengadakan acara-acara/kegiatan yang melibatkan semua anggota Polri Sektor Belakang Padang ( BLP ).

\section{DAFTAR PUSTAKA}

Agung Thamrin. 2012, Manajemen Sumber Daya Manusia, Jakarta : Raja Grafindo

Gibson. 2011 Organisasi, Struktur, Proses Manajemen Sumber Daya Manusia, Jakarta: Bina Rupa Aksara

Malayu P Hasibuan, 2002, Manajemen Sumber Daya Manusia, Jakarta : PT Bumi Aksara

Sumber Daya Manusia Edisi Revisi, Jakarta : PT Bumi Aksara

Prawirosentono. 2012, Manajemen Sumber Daya Manusia , Bandung : Remaja Rosdakarya

Prijodarminto. 2004, Kiat Menjadi Manajemer Sukses, Jakarta : Pradya Paramita

Sinungan. 2005, Manajemen Sumber Daya Manusia, Bandung : Ghalia Indonesia

Sugiono, 2004 Metodologi Penelitian Bisnis, Bandung: CV Alfabeta

T. Hani Handoko, 2002 Manajemen Personalia dan Sumber Daya Manusia Cetakan ke Duabelas, Yogyakarta: BPFE

Veithzal Rivai.2004. Manajemen Sumber Daya Manusia Untuk Perusahaan

Dari Teori ke Praktek, PT Raja Grafindo Persada ; Jakarta

Werther William, Davis. 2006, Human Resources and Personnel, Jakarta : McGraw-Hill 